\title{
Land Subsidence Analysis of Reclaimed Land using Time-Lapse Microgravity Anomaly in Manado, Indonesia
}

\author{
Sandy Nur Eko Wibowo ${ }^{1,}$, Gybert E. Mamuaya ${ }^{2}$, Rignolda Djamaluddin ${ }^{2}$ \\ ${ }^{1}$ BMKG Stasiun Geofisika Manado, Jl. Harapan, Winangun, Manado 95161, Indonesia. \\ ${ }^{2}$ Faculty of Fisheries and Marine Science, Universitas Sam Ratulangi, Jl. Kampus, Bahu, Manado \\ 95115, Indonesia. \\ *) Corresponding author (e-mail: Le345an4ever@gmail.com)
}

Received: 15 March 2018 / Accepted: 08 May 2018 / Published: 27 May 2018

\begin{abstract}
Coastal area land reclamation is a policy with various benefits, including its potential to increase economic growth. However, reclamation also potentially has adverse impacts on the environment, including increasing pressure on biodiversity, natural resources and natural ecosystems, and the most common problem is land subsidence. This study uses time-lapse microgravity anomaly to ascertain the distribution of gravity and vertical gradient anomaly in order to map the subsidence characteristics occurring in the Manado reclamation area. From the research that has been previously conducted, the positive gravity anomaly is spread around Megamall-Multimart to the north of Monaco Bay and on the southern side of Manado Town Square (Mantos). Positive anomaly values range from 3 to $29.7 \mu \mathrm{Gal}$. The negative anomaly values are scattered around the Mantos and Megamas separating bridge and at some points around the Whiz Prime Hotel, Menora Church and towards the Pohon Kasih Megamas area. The reclaimed areas generally experience subsidence accompanied by a reduction in groundwater mass (Megamall and Mantos) due to the use of the groundwater by the community in these areas. Uplifts also occur at some points in the reclamation area of Megamas as a result of the occurrence of land subsidence. Longer-term research is needed to determine whether there is an increase in the rate of land subsidence in the Manado reclamation area. Over a longer period of time it can also be established whether there are other factors which affect land subsidence. Other geodetic methods to monitor subsidence, such as levelling, InSAR and GPS survey, which have been conducted in other locations, are also needed to obtain more detailed information about the land subsidence in this area.
\end{abstract}

Keywords: land subsidence, groundwater, reclamation, time-lapse, microgravity, anomaly, vertical gradient, Manado.

\footnotetext{
Abstrak. Manado, dengan jumlah penduduk yang berkisar 430.790 jiwa tentunya membutuhkan terobosan dalam rangka peningkatan pertumbuhan ekonomi masyarakatnya. Pusat perekonomian di Manado mulanya terkonsentrasi di seputar Taman Kesatuan Bangsa dan Pasar 45, namun seiring dengan pertumbuhan ekonomi, industri retail dan properti berkembang cukup pesat. Salah satu kebijakan dalam menyiasati kondisi ini adalah kegiatan reklamasi di daerah pantai Manado, khususnya di sepanjang Jalan Tepi Pantai Boulevard (Lahan Megamas). Di balik beberapa manfaatnya, kegiatan reklamasi berpeluang menimbulkan dampak terhadap banyak hal, antara lain meningkatkan tekanan terhadap keanekaragaman hayati, sumber daya alam dan ekosistem alami dan mengakibatkan terjadinya amblesan tanah. Penelitian menggunakan anomali gaya berat antar waktu bertujuan untuk mengetahui sebaran nilai anomali dan nilai gradien vertikal gaya berat antar waktu hingga dapat dipetakan karakteristik amblesan yang terjadi di lahan reklamasi Manado. Dari penelitian yang telah dilakukan didapatkan anomali gaya berat antar waktu positif tersebar di sekitar lahan Megamall-Multimart ke arah utara menuju ke lahan Monaco Bay dan di lahan Manado Town Square (Mantos) sebelah selatan. Nilai anomali positif berkisar antara 3 hingga 29,7 $\mu$ Gal. Nilai anomali negatif tersebar di sekitar jembatan pemisah Mantos dan Megamas dan beberapa titik di sekitar Hotel Whiz Prime, Gereja Menora ke arah lahan Pohon Kasih Megamas. Nilai anomali negatifberkisar antara - 3 hingga - 29,9 $\mu$ Gal. Lahan reklamasi Manado secara umum mengalami amblesan yang dibarengi dengan pengurangan massa air tanah akibat penggunaan massa air tanah untuk keperluan masyarakat di lahan reklamasi. Pengangkatan permukaan juga terjadi di beberapa titik di lahan reklamasi Megamas sebagai dampak terjadinya amblesan tanah.
} 
Penelitian jangka panjang diperlukan untuk menentukan apakah ada peningkatan laju penurunan tanah di daerah reklamasi Manado. Dengan waktu penelitian yang lebih lama, dapat juga diketahui apakah ada faktor lain yang mempengaruhi penurunan tanah. Metode geodetik lain untuk memantau amblesan seperti metode Levelling, Survey GPS dan InSAR, yang telah dilakukan di lokasi lain, juga diperlukan untuk memperoleh informasi lebih rinci tentang amblesan tanah di daerah reklamasi Manado.

Kata Kunci: amblesan tanah, air tanah, reklamasi, anomali gaya berat antar waktu, gradien vertikal gaya berat antar waktu, Manado.

\section{Introduction}

Manado and other cities in Indonesia have implemented reclamation in their coastal areas. Economic activity in Manado was first concentrated in the city centre. The retail and property industries developed along with the economic growth of the city, the impact of which significantly reduced land space. The government, therefore, planned land reclamation of the coastal areas. The reclamation policy was in accordance with the concept of the "Waterfront City", which was the planning concept for Manado (Kalalo, 2009).

Beside their benefits, reclamation activities also have the potential to increase pressure on biodiversity, natural resources and natural ecosystems (Widodo, 2005), which might lead to land subsidence (Soedarsono and Marfai, 2012). The situation of the Manado reclamation area, as the centre of the economic activity of the city, with the associated level of new construction, is assumed to have led to more groundwater usage. Four main factors cause land subsidence: groundwater extraction, a high level of construction, natural consolidation of alluvial soil, and tectonic activities (Abidin et al., 2011). Land subsidence caused by excessive groundwater extraction is one dominant type of subsidence found in large cities (Setyarini and Sugi, 2008). Medium to serious degradation conditions in the Marina reclamation area in Semarang, East Java Province, is one example of land subsidence due to coastal reclamation (Soedarsono and Marfai, 2012). Referring to these conditions, research is needed to determine the extent of subsidence and the decrease in groundwater levels in the Manado reclamation area.

Several geodetic methods have been used to monitor land subsidence, such as levelling (Sutanta et al., 2005; Marfai and King, 2007); GPS survey (Abidin et al., 2011); gravity (Sarkowi et al., 2005); and Interferometric Synthetic Aperture Radar / InSAR (Lubis et al., 2011). In this study, the gravity method (Time Lapse Microgravity Anomaly method) is used, which employs manual (moveable) equipment, which is easy to move around, causes no environmental damage, needs minimum electricity support, only requires a small team, and leads to little social conflict. The method has been used to detect and monitor subsidence by combining gravity and geological data to study the history of subsidence in the United Arab Emirates (Ali and Walts, 2009) and the time-lapse microgravity method has been used to monitor subsidence in Cheshire, UK (Stewart et al., 2000). The results of this study are expected to provide useful suggestions and inputs for future development planning of the Manado area, and may lead to other scientific studies related to land subsidence in the Manado reclamation area.

\section{Research Method}

Measurements of time-lapse gravity were conducted twice in January and May 2017. The study was located in the Manado Reclamation Area, with 32 measurement points, as shown in Figure 1. While the detail information of the measurement points is provided in Table 1. The measurements were made using a Gravimeter Scintrex Autograv CG-5. This instrument measures gravity values and vertical gravity gradients. Other supporting equipment were computers for processing and data analysis, GPS and the ESRI ArcGIS 10.3 mapping application. The measurements at each location were made twice, with different instrument height positions above the ground. The first measurement was at ground level (the height position of the instrument was considered to be zero 0 ), while the second was made at a height of $100 \mathrm{~cm}$ above the ground surface. 


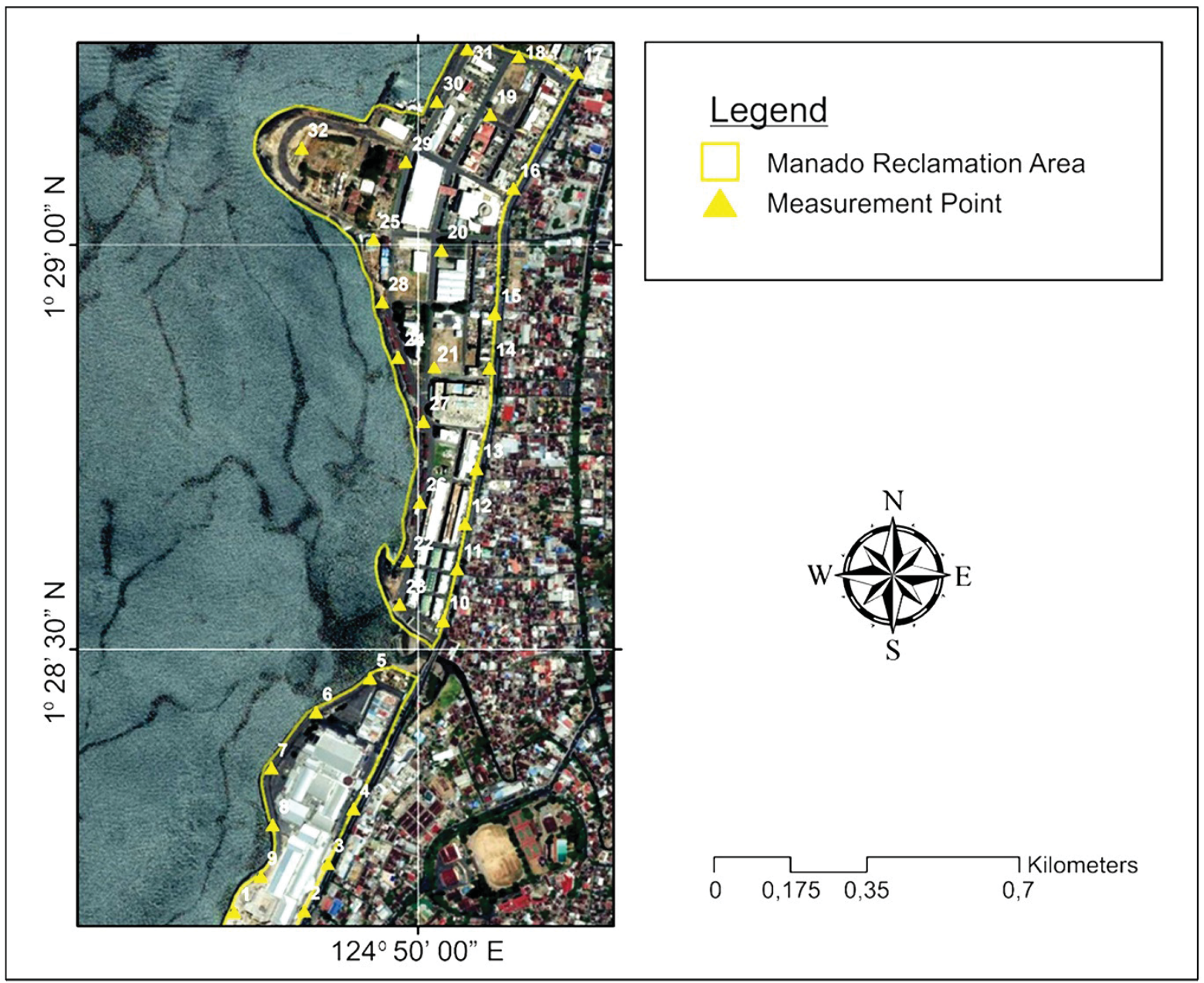

Figure 1. Distribution of measurement points in the reclamation area.

The measurement results were analysed using several formulae to identify gravity anomaly. The Complete Bouguer Anomaly equation illustrates a mass density change (Equation 1). Where $g_{\text {obs }}$ and $g_{t}$ are the observed and theoretical gravity values; $a, b$, and $c$ are the free-air constants, Bouguer correction and terrain correction; is the density; $h$ the elevation (above sea level); and is the station elevation difference to the area surrounding the location. Measurements at each point were made twice, with a time interval of around 4 months. If the first and second measurement times are $\mathrm{t} 1$ and $\mathrm{t} 2$, the gravity anomaly of each measurement point is given in Equation 2 (first measurement) and 3 (second measurement).

$$
\begin{aligned}
& \Delta g_{B}(x, y, z)=g_{o b s}(x, y, z)-g_{t}(x, y, z)+ \\
& a h(x, y, z)-b \rho_{B} h(x, y, z)+c \Delta h(x, y, z) \\
& \Delta g_{B}\left(x, y, z, t_{1}\right)=g_{o b s}\left(x, y, z, t_{1}\right)-g_{t}\left(x, y, z, t_{1}\right)+ \\
& a h\left(x, y, z, t_{1}\right)-b \rho_{B} h\left(x, y, z, t_{1}\right)+c \Delta h\left(x, y, z, t_{1}\right) \\
& \Delta g_{B}\left(x, y, z, t_{2}\right)=g_{o b s}\left(x, y, z, t_{2}\right)-g_{t}\left(x, y, z, t_{2}\right)+ \\
& a h\left(x, y, z, t_{2}\right)-b \rho_{B} h\left(x, y, z, t_{2}\right)+c \Delta h\left(x, y, z, t_{2}\right)
\end{aligned}
$$


Table 1. Measurement points in the reclamation area

\begin{tabular}{|c|c|c|c|}
\hline No. & Latitude & Longitude & Remark \\
\hline 1 & 1.4696 & 124.8295 & Area behind CENTRO - MANTOS 3 \\
\hline 2 & 1.4696 & 124.8310 & CENTRO Area - MANTOS 3 \\
\hline 3 & 1.4706 & 124.8315 & JCO Area - MANTOS 2 \\
\hline 4 & 1.4717 & 124.8320 & MANTOS 2 Area \\
\hline 5 & 1.4744 & 124.8323 & Area behind MANTOS 1 (Security Area) \\
\hline 6 & 1.4737 & 124.8312 & Area behind MANTOS 1 \\
\hline 7 & 1.4726 & 124.8303 & Area in front of KFC - MANTOS 2 \\
\hline 8 & 1.4714 & 124.8303 & Area in front of MATAHARI Dept. Store - MANTOS 3 \\
\hline 9 & 1.4703 & 124.8301 & Area behind MANTOS 3 \\
\hline 10 & 1.4756 & 124.8339 & "Rumah Alam Megamas" Area \\
\hline 11 & 1.4767 & 124.8341 & “Optik Internasional” Area \\
\hline 12 & 1.4776 & 124.8343 & "VIVO Megamas" Area \\
\hline 13 & 1.4787 & 124.8345 & “Bank Papua Megamas" Area \\
\hline 14 & 1.4808 & 124.8348 & "Amarylis Florist Megamas" Area \\
\hline 15 & 1.4819 & 124.8349 & "Bank Mandiri Syariah Megamas" Area \\
\hline 16 & 1.4845 & 124.8353 & Megamall - Multimart Megamas \\
\hline 17 & 1.4869 & 124.8366 & Grand Hardware parking area \\
\hline 18 & 1.4872 & 124.8354 & Megamas Field Area \\
\hline 19 & 1.4860 & 124.8348 & Megamas Field Area \\
\hline 20 & 1.4832 & 124.8338 & Megamall Parking Area \\
\hline 22 & 1.4768 & 124.8331 & “Kelompok Nelayan Tarusi” Area \\
\hline 23 & 1.4759 & 124.8330 & "Jangkar Sandar" Area \\
\hline 24 & 1.4810 & 124.8329 & Whiz Prime Hotel \\
\hline 25 & 1.4835 & 124.8324 & "Youth Center Megamas" Area \\
\hline 26 & 1.4780 & 124.8334 & “Minahasa Star Café" Area \\
\hline 27 & 1.4797 & 124.8334 & “Bunaken Café" Area \\
\hline 28 & 1.4822 & 124.8326 & Menora Church Area \\
\hline 29 & 1.4851 & 124.8331 & Area behind Multimart Megamas \\
\hline 30 & 1.4863 & 124.8337 & "De'Selmar Café" Area \\
\hline 31 & 1.4874 & 124.8343 & McDonald Megamas Area \\
\hline 32 & 1.4853 & 124.8309 & "Pohon Kasih Megamas" Area \\
\hline
\end{tabular}

The time-lapse microgravity anomaly is using free air and Bouguer correction as a obtained from the difference in values between result of the different measurement heights at the first and second measurements, as shown each point. A height change of $1 \mathrm{~cm}$ is indicated in Equation 4. This equation shows that time- by an anomalous value of $3.4 \mu \mathrm{Gal}$ (Allis and lapse microgravity anomalies can be eliminated Hunt, 1984).

$\Delta g(x, y, z, \Delta t)=g_{o b s}\left(x, y, z, t_{2}\right)-g_{o b s}\left(x, y, z, t_{1}\right)+$

$a \Delta h(x, y, z, \Delta t)-b \rho_{B} \Delta h(x, y, z, \Delta t)$ 


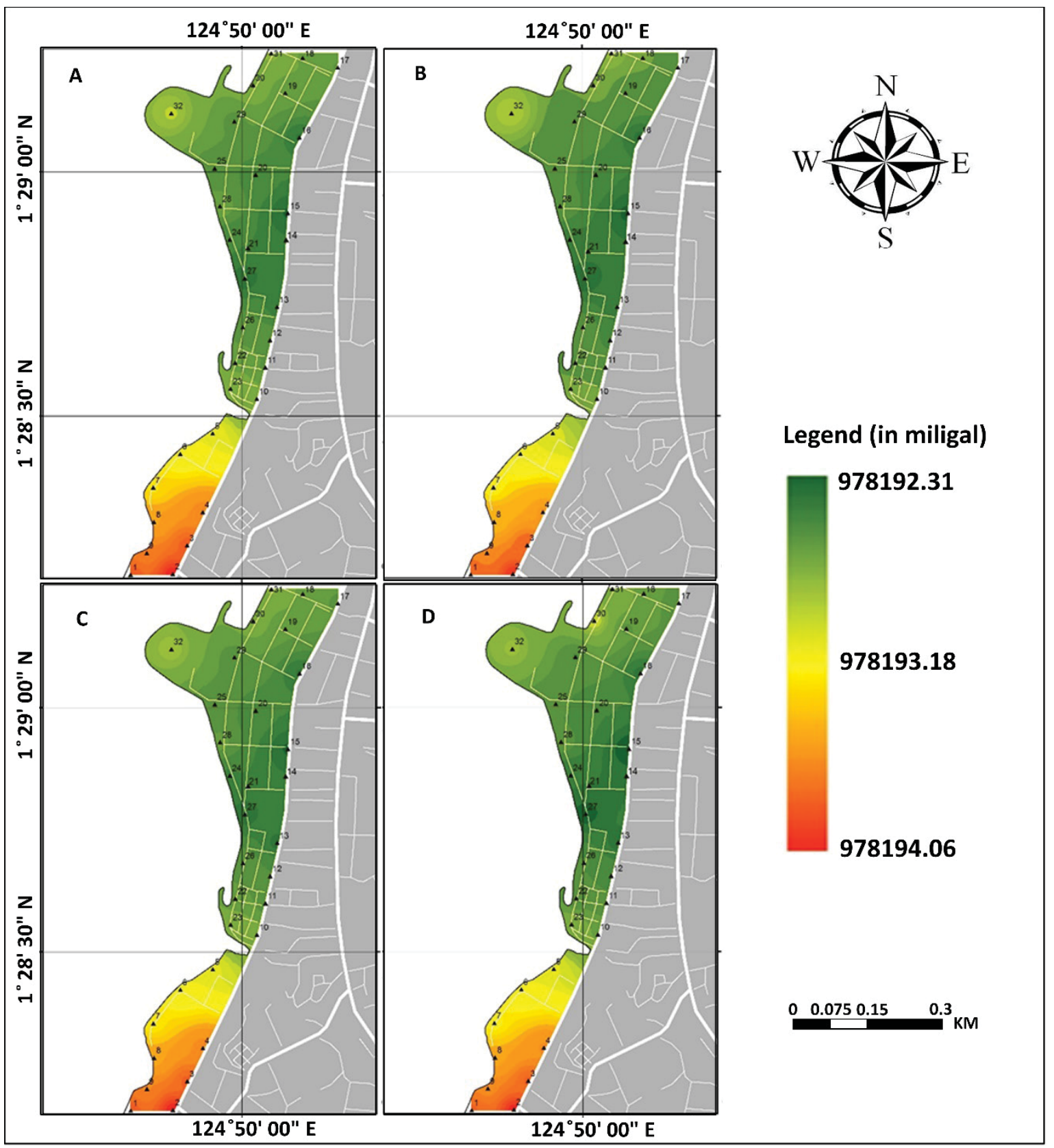

Figure 2. Mapping of gravity values. (A) The first measurement at ground level; (B) The first Measurement at 1 metre over ground level; (C) The second Measurement at ground level (D) Second Measurement at 1 metre over ground level

In addition to using free air and Bouguer correction, rainfall correction was also needed to reduce the effect of increased groundwater due to rainfall so that the positive anomaly value is represented only by land subsidence. By using the exponential formula of Akasaka and Nakanishi (2000), the empirical relation between precipitation and change in groundwater level can be calculated (Equation 5). In this formula, $\mathrm{H}_{1}$ is the initial groundwater level; $\mathrm{t}$ is time; $\mathrm{t}_{\mathrm{n}}$ is the time to $\mathrm{n} ; \mathrm{\alpha}$ is the absorption constant; $\mathrm{c}$ is the evaporation constant; and $R_{n}$ is precipitation on the day $\mathrm{n}$ from the first day $(\mathrm{mm})$. The value of $\mathrm{H}_{1}$ for the initial state is considered to be 0 , so we can establish the $\mathrm{H}$ change value of the location from the empirical results.

$$
H(t)=H_{1}+\propto \sum n R_{n} \exp \left\{-c\left(t-t_{n}\right)\right\}
$$






Figure 3. Mapping of the gravity vertical gradient of the first $(A)$ and second $(B)$ measurements.

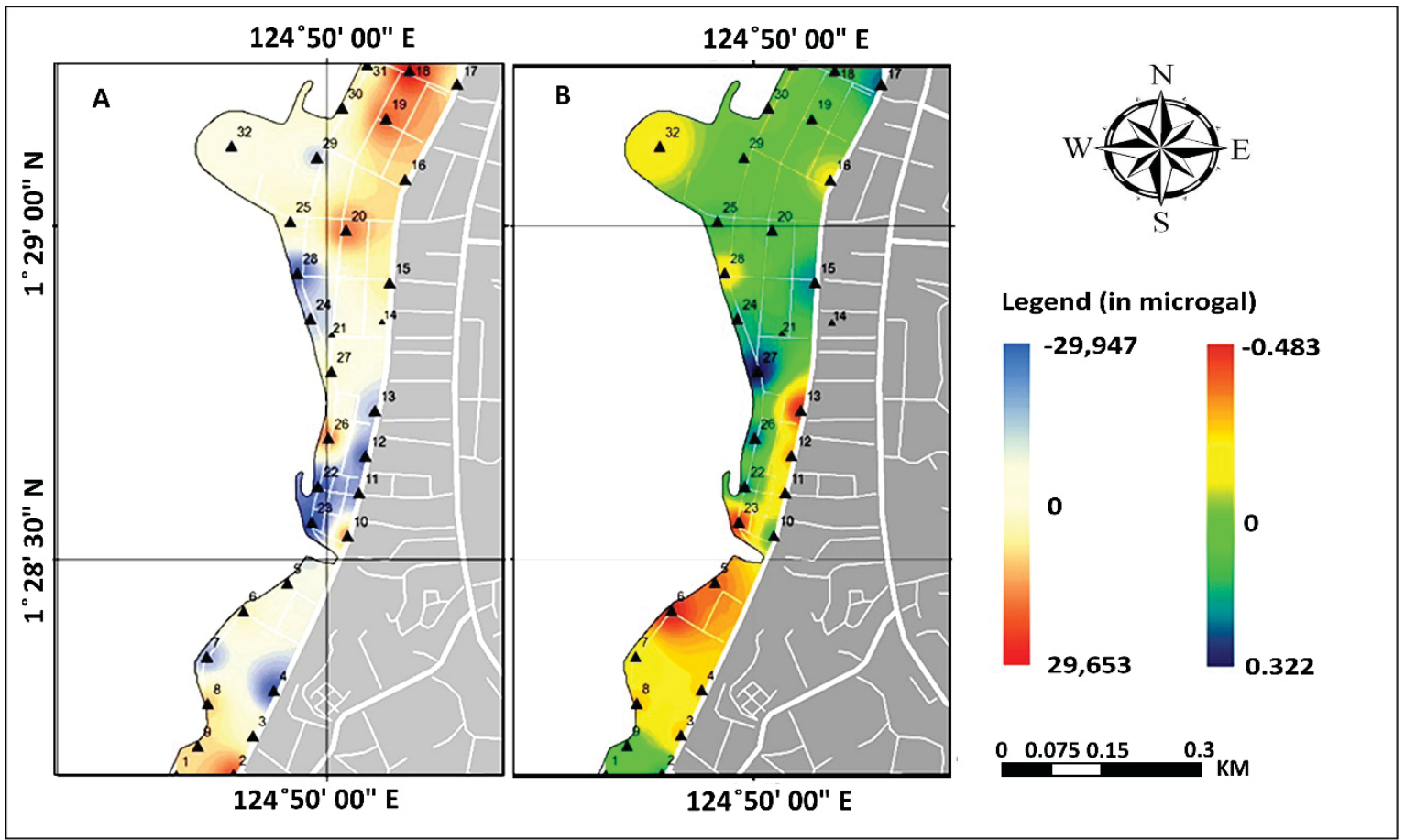

Figure 4. (A) Mapping of time-lapse microgravity anomaly. (B) Mapping of time-lapse gravity vertical gradient.

After we obtain the change value of $\mathrm{H}$, we can then calculate the change in gravity value caused by the change in $\mathrm{H}$ using Equation 6 (Allis and Hunt, 1984). Where is the gravity anomaly due to changes in groundwater level; $\mathrm{G}$ is the universal gravity constant $(\mathrm{G}=6.67 \mathrm{x}$ $10-11 \mathrm{~m}-3 \mathrm{~kg}-1 \mathrm{sec} 2) ; \varnothing$ is the porosity of the soil reservoir (\%); is the groundwater density (gr / cc); and is the change in groundwater level (metres). If rock porosity is assumed to be $30 \%$ (Marsudi, 2000) and soil density $1 \mathrm{gr} /$ $\mathrm{cc}$, then any change of 1 metre in groundwater will result in a change of gravity value of about $12.579 \mu \mathrm{Gal}$. 
Table 2. Relationship between time-lapse gravity anomalies and time-lapse gravity vertical gradient anomalies.

\begin{tabular}{ccl}
\hline $\begin{array}{c}\text { Time-lapse Microgravity } \\
\text { anomaly }\end{array}$ & $\begin{array}{c}\text { Time-lapse Gravity vertical } \\
\text { gradient anomaly }\end{array}$ & \multicolumn{1}{c}{ Anomaly Source } \\
\hline$(+)$ & $(+)$ & $\begin{array}{l}\text { Land subsidence and addition of subsurface mass, or } \\
\text { just addition of subsurface mass }\end{array}$ \\
$(+)$ & 0 & $\begin{array}{l}\text { Land subsidence } \\
\text { Reduction of subsurface mass / land subsidence } \\
(+)\end{array}$ \\
$(-)$ & $(-)$ & $\begin{array}{l}\text { Reduction in subsurface mass } \\
\text { Reduction in subsurface mass same with land sub- } \\
\text { sidence }\end{array}$ \\
\hline
\end{tabular}

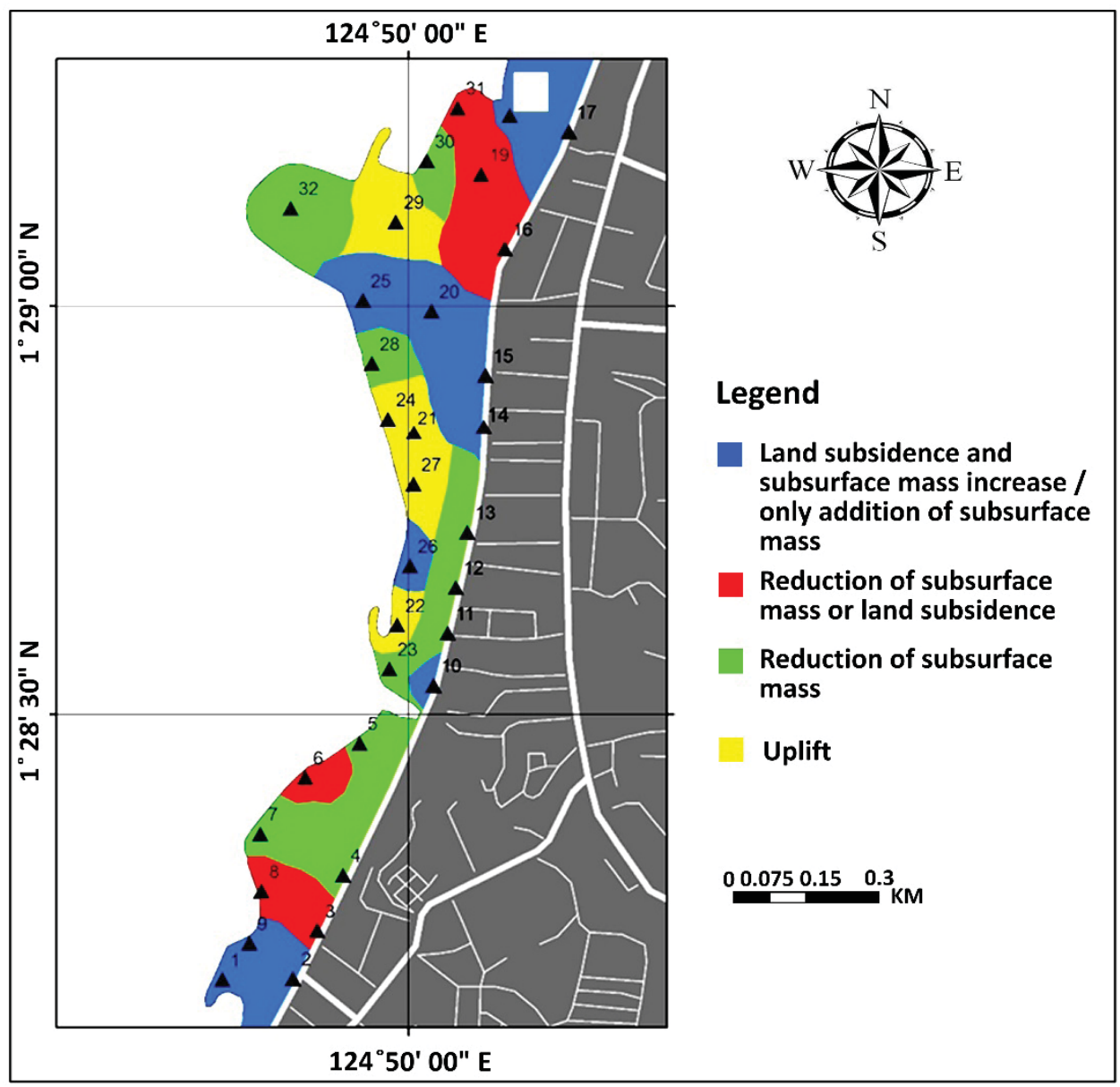

Figure 5. Mapping of time-lapse microgravity anomaly source zonation.

$$
\Delta g=2 \pi G \emptyset \rho_{w} \Delta H
$$

\section{Results and Discussion}

Microgravity measurements were made twice in the Manado reclamation area over a four-month period between January and May 2017. Elevation measurement using GPS was also used to support the analysis. To obtain the observed gravity value, tidal, drift and rainfall corrections were applied to its measurement. From the first and second measurements in January and May 2017 we obtained the
(6) gravity data shown in Figure 2, consisting of the measurement results at ground level and 1 metre above ground level.

The gravity values obtained from the first measurement (Figure 2A) range from 978192.563 - $978194.3125 \mathrm{mGal}$ for the measurements at ground level and 978192.3125 - $978194.0625 \mathrm{mGal}$ for those at the height of 1 metre over ground level (Figure 2C). The results of the second gravity measurements in May 2017 are shown in Figure 2B for those at ground level, and in Figure 2D, for those 1 metre above 
ground level. The gravity values of the second measurement range from $978192.5625 \mathrm{mGal}$ to $978194.375 \mathrm{mGal}$ for those at ground level, and $978192.313 \mathrm{mGal}$ to 978194.063 for those 1 metre above ground level. The results of first and second measurements determine the gravity vertical gradient of each measurement (shown in Figure 3).

Time-lapse microgravity anomaly reflects several sources, such as a change in station elevation, fluid movement, and density change in the subsurface. Gravity anomaly is a superposition of all possible sources. In order to separate each source that caused the anomaly, we need to combine the time-lapse microgravity anomaly with its vertical gradient. After obtaining the values of the time-lapse gravity anomalies and the vertical gradients, they were both mapped, as shown in Figure 4. The values are obtained by the difference between the first and second measurements.

Figure $4 \mathrm{~A}$ shows that the positive gravity anomaly spreads north from the MegamallMultimart to the Monaco Bay and the southern side of Mantos. The positive gravity anomaly values range from 3 to $29.7 \mu \mathrm{Gal}$. The highest positive anomaly value was found in the Megamall-Multimart area up to Monaco Bay area, at 18 to $29.7 \mu \mathrm{Gal}$. The negative anomalies (the regions with blue gradations in Figure 4A) are scattered around the Mantos and Megamas bridges, with some points around the Whiz Prime Hotel and Menora Church towards the Pohon Kasih Megamas area. The negative gravity anomaly values range from -30 to $-6 \mu \mathrm{Gal}$. The regions with the highest negative anomaly values are those around the "Jangkar Sandar" and Menora Church (-30 to $-23 \mu \mathrm{Gal})$. The time-lapse gravity vertical gradient anomalies are obtained from the gravity vertical gradient differences between the first and second measurements. Where the anomalous values range from -3.06 to $0.55 \mu \mathrm{Gal}$. To determine the source of these anomalies, we use the relationship between the time-lapse gravity anomalies and the time-lapse gravity vertical gradient anomalies, as shown in Table 2 .
Using the relation between the gravity values, gravity vertical gradients and gravity anomaly sources, the characteristics of the land subsidence and groundwater level can be ascertained. The time-lapse microgravity anomaly zonation source map is shown in Figure 5. Based on data from PT. Mega Jasa Kelola, the Megamas reclamation developer, the area has several drilled wells with a depth of about 100 metres at some points. The dominant drilled well, which is still operating, is located in front of the Megamall area and behind the "Ruko Benua Elektronik" area. This information supports the time lapse microgravity anomaly mapping results (Figure 4A), in which positive anomalies in the Megamas area were detected around the Megamall-Multimart zone. This is also reinforced by the results of timelapse microgravity anomaly source zonation mapping, which shows that land subsidence, accompanied by groundwater mass reduction, has also occurred in that area. The loading of buildings that has resulted in consolidation of the soil, accompanied by the extraction of groundwater, are factors that might have led to land subsidence (Reddish and Whittaker, 2012). At some measurement points directly adjacent to the areas that are experiencing subsidence, there is an uplift (areas in yellow in Figure 5). This phenomenon may occur in the sediment material if some of it is subjected to pressure from above. In general, the material used in the Manado reclamation area is a sediment material (alluvium), which has not been compacted so is prone to land subsidence (Bemmelen, 1949).

The embankment material in the Manado reclamation area comes from the Manado Ring Road and Kalasey area (Sa' pang et al., 2015). The Manado geological map (Effendi and Bawono, 1997) shows that the material in the Manado Ring Road and Kalasey is young volcanic rock $(\mathrm{Qv})$ and Tondano tuff $(\mathrm{Qtv})$. The young volcanic rock consists of lava, bombs, lapilli and volcanic ash, which are unconsolidated pyroclastic rocks, while Tondano tuff consists of andesite material, which is consolidated pyroclastic rock (Williams et al., 1982). The reclamation embankment material composed 
of unconsolidated pyroclastic rocks was placed on the original material of the Manado Bay area, which is alluvium rock (Qal) and sedimentary rocks from lakes and rivers (Qs) consisting of low to medium resistance sediment such as gravel, sand and clay, which are likely to experience land subsidence (Sophian, 2010). Due to the high compressibility, low permeability and weakness of the alluvial clay (Zhang et al., 2002), the soil becomes compacted under the pressure from the embankment material, construction and soil self-consolidation. This compaction process can cause ground deformation (Wang et al., 2012), which can in turn lead to land subsidence. In addition to soil consolidation and groundwater mass extraction, there are also several general factors which affect land subsidence, namely particle size and soil form, soil mineralisation and the possibility of secondary compression (Poland and Davis, 1969).

Land subsidence can be monitored through measurement of the gravity anomaly. Every change of $1 \mathrm{~cm}$ in height is indicated by a gravity anomaly value of $3.4 \mu \mathrm{Gal}$ (Allis and Hunt, 1984), so the rate of land subsidence in the reclamation area can be calculated from the gravity anomaly value results, which range from $0.01-0.20$ metres/year. This rate of land subsidence is of a low to medium level. The rate of land subsidence occurring in the Manado reclamation area has the same category as that of the reclamation areas of Marina Beach Semarang and North Jakarta. The rate of subsidence in the Semarang reclamation area is in the medium category, ranging from 0.10 to 0.20 metres /year (Soedarsono and Marfai, 2012), while the rate in North Jakarta is from 0.08 to 0.13 metres/year (Minardi et al., 2010). At first, the rate of land subsidence in Semarang was included in the medium category (from 0.10 to 0.20 metres/year). However, in line with the development that has taken place in the Marina Beach reclamation area, the rate of subsidence increased to the high category rate (>0.20 metres/year) in 2010 (Soedarsono and Marfai, 2012). Based on this study of Soedarsono and Marfai (2012), it is known that the rate of land subsidence in the reclamation area may increase along with the building development above it. The loading of the buildings might lead to the consolidation of the land underneath. The greater the force of the building pressure, the higher the soil consolidation in a vertical direction (Hancock and Skinner, 2000).

There are several solutions to reduce the rate of land subsidence, such as the complete cessation of mass groundwater extraction, or restoration of pressure on groundwater masses by artificial replenishment/pressure delivery by water injection, as done in Wilmington, California (Poland and Davis, 1969). Stopping the extraction of groundwater mass is difficult to achieve, as the process of the mass extraction of groundwater is intended to meet the needs of the community around the reclamation area. Artificial refilling with water injection is a step that can be taken as an alternative solution to reducing the rate of subsidence in the reclamation area.

\section{Conclusion and Recommendation}

Time-lapse microgravity anomaly was used in this study to monitor the occurrence of land subsidence in reclamation land in Manado. This study found that (1) the positive gravity anomaly spreads north around MegamallMultimart to Monaco Bay and on the southern side of Mantos. The positive anomaly values range from 3 to $29.7 \mu \mathrm{Gal}$. Negative anomalies are scattered around the Mantos-Megamas bridges and at some points around the Whiz Prime Hotel, Menora Church and towards the "Pohon Kasih Megamas" area. (2) the timelapse gravity vertical gradient anomaly values range from -0.48 to $0.32 \mu \mathrm{Gal}$. (3) The Manado reclamation area generally experiences land subsidence accompanied by mass groundwater reduction due to the extraction of the water for the community in the reclamation areas. Uplifts also occur at some point in reclamation area as a result of land subsidence. (4) The rate of land subsidence occurring in the Manado reclamation area is in the low to medium category (from 0.01 to 0.20 metres / year).

Longer-term research is needed to determine whether there is an increase in 
the rate of land subsidence in the Manado reclamation area. With a more extended research period, it could also be established whether there are other factors that affect the land subsidence. Other geodetic methods to monitor subsidence, such as levelling, InSAR and GPS surveys, which have been conducted in Semarang, are also needed to obtain more detailed information about land subsidence in the Manado reclamation area.

\section{Reference}

Abidin, H.Z., Jones, A. and Kahar, J. (2011). Surveying with GPS (in Indonesian). (Bandung: Penerbit ITB (ITB Press)). ISBN 978-602-9056-01-3, 261 pp.

Akasaka, C. and S. Nakanishi. (2000). Correction of Background Gravity Changes Due to Precipitation in the Oguni Geothermal Field, Japan. Proceedings World Geothermal Congress, pp. 2471-2475.

Ali, M.Y. and Walts, A.B. (2009). Subsidence History, Gravity Anomalies and Flexure of The United Arab Emirates (UAE) Foreland Basin. GeoArabia, Vol. 14 No.2, 17 - 44.

Allis, R.G. and T.H. Hunt. (1984). Modelling The Gravity Changes at Wairakei Geothermal Field. Proc. 6th NZ Geothermal Workshop:117-12

Allis, R.G. and Hunt, T.M. (1986). Analysis of exploitation induced gravity changes at Wairakei Geothermal Field. Geophysics, 51, 1647-1660.

Bemmelen, R.W. van. (1949). The Geology of Indonesia Vol. IA. General Geology. Government Printing Office: The Hague, $732 \mathrm{~h}$.

Effendi, A.C. and Bawono, S.S. (1997). Geological Map of The Manado Sheet, North Sulawesi. Pusat Penelitian dan Pengembangan Geologi. Hal. 2416-2417.

Hancock, P. and Skinner, B.J. (2000). Compaction and Consolidation of Soil. The Oxford Companion to the Earth. Oxford: Oxford University Press.

Kalalo, F. (2009). Implikasi Hukum Kebijakan Reklamasi Pantai dan Laut di Indonesia. Buku I. Bandung: LoGoz Publishing.

Poland, J. F. and Davis, G.H., (1969). Land Subsidence due to withdrawal of fluids. A.R. Eng. Geol, USGS, Sacra and Wash, DC, 2, pp. 187-269.

Lubis, A.M., Sato, T., Tomiyama, N., Isezaki, N. and Yamanokuchi, T. (2011). Ground subsidence in Semarang-Indonesia investigated by ALOS-PALSAR satellite SAR interferometry. Journal of Asian Earth Sciences, 40, pp. 1079-1088.

Marfai, M.A. and King, L. (2007). Monitoring land subsidence in Semarang, Indonesia. Environmental Geology, 53, pp. 651-659.

Marsudi, M. (2000). Prediksi Laju Amblesan Tanah di Dataran Alluvial Semarang Propinsi Jawa Tengah.Disertasi Program Pascasarjana ITB.

Minardi, S., Hiden, Dahrin, D. and Yusuf, M. (2014). Analisa Penurunan Airtanah dan Amblesan Tanah dengan Metode Gayaberat Mikro dan Gradien Vertikal Antar Waktu : Studi Kasus di Jakarta. Jurnal Ilmu Dasar, 15 (1), hal. 7 - 14.

Reddish, D. J., \& Whittaker, B. N. (2012). Subsidence: occurrence, prediction and control (Vol. 56). Elsevier.

Sa'pang, R.O., Balamba, S. and Sumampouw, J. (2015). Pengaruh Jenis Tanah Terhadap Kestabilan Struktur Embankment di Daerah Reklamasi (Studi Kasus Malalayang). Jurnal TEKNO Fakultas Teknis Universitas Sam Ratulangi, 13 (62).

Sarkowi, M., Kadir, W.G.A. and Santoso, D. (2005). Strategy of 4D microgravity survey for the monitoring of fluid dynamics in the subsurface. In Proceedings of the World Geothermal Congress 2005, 24-29 April 2005, Antalya, Turkey 
Setyarini and Sugi, A. (2008). Analysis of Land Subsidence Effect to Word Land Value. Case Study Sub District Penjaringan - North Jakarta.

Soedarsono and M. A. Marfai. (2012). Monitoring The Change Of Land Subsidence In The Nothern Of Semarang Due To Change Of Landuse On alluvial Plain. Analele Universitắ́ii din Oradea. Seria Geografie, 1, 54 - 65.

Sophian, R.I. (2010). Penurunan Muka Tanah di Kota- Kota Besar Pesisir Pantai Utara Jawa (Studi Kasus: Kota Semarang). Bulletin of Scientific Contribution 8 (1), hal. 41-60.

Stewart, J., Watts, A. B. and Bagguley, J. G. (2000). Three Dimensional Subsidence Analysis and Gravity Modelling of The Continental Margin Offshore Nambia,. Geophys. J. Int., 141, 724 $-746$.

Sutanta, H., Rachman, A., Sumaryo and Diyono, (2005). Predicting land use affected by land subsidence in Semarang based on topographic map of Scale 1:5.000 and leveling data. In Proceedings of the Map Asia 2005 Conference (in CD Rom), 22-25 August 2005, Jakarta.

Wang, H., Wright, T.J., Yu, Y., Lin, H., Jiang, L., Li, C., and Qiu, G. (2012). InSAR reveals coastal subsidence in the Pearl River Delta, China. Geophys. J. Int., 191, 1119-1128

Widodo, L. (2005). Kecenderungan Reklamasi Wilayah Pantai dengan Pendekatan Model Dinamik. Jurnal Teknologi Lingkungan, 6 (1), 330-338.

Williams, H., Turner, F. and Gilbert, C.M. (1982). Petrography an Introduction to the Study of Rocks in Thin Section. Second Edition, New York: W.H. Freeman and Company, pp. 267-271.

Zhang, H.M., Xu, Y.S. and Zeng, Q.L. (2002). Deformation behavior of shenzhen soft clay and post-construction settlement. Chin. J. Geotech. Eng., 24, 509-514. (In Chinese with English Abstract) 